\title{
Analysis of Business Strategies of Xiaomi
}

\author{
Safiya H. M. ${ }^{1}$ \& Shylesh $\mathrm{S}^{2}$ \\ ${ }^{1}$ Student of MCA, College of Computer \& Information Science, Srinivas University, \\ Mangalore-575001, INDIA \\ ${ }^{2}$ College of Computer \& Information Science, Srinivas University, Mangalore-575001, India \\ E-mail: safiamh12@gmail.com
}

Type of the Paper: Case Study.

Type of Review: Peer Reviewed.

Indexed In: OpenAIRE.

DOI: http://doi.org/10.5281/zenodo.2574499.

Google Scholar Citation: IJCSBE

\section{How to Cite this Paper:}

H. M., Safiya, \& S., Shylesh. (2019). Analysis of Business Strategies of Xiaomi. International Journal of Case Studies in Business, IT, and Education (IJCSBE), 3(1), 1-8. DOI: http://doi.org/10.5281/zenodo.2574499.

International Journal of Case Studies in Business, IT and Education (IJCSBE) A Refereed International Journal of Srinivas University, India.

(C) With Authors.

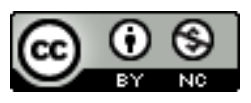

This work is licensed under a Creative Commons Attribution-Non Commercial 4.0 International License subject to proper citation to the publication source of the work.

Disclaimer: The scholarly papers as reviewed and published by the Srinivas Publications (S.P.), India are the views and opinions of their respective authors and are not the views or opinions of the S.P. The S.P. disclaims of any harm or loss caused due to the published content to any party. 


\title{
Analysis of Business Strategies of Xiaomi
}

\author{
Safiya H. M. ${ }^{1}$ \& Shylesh $\mathrm{S}^{2}$ \\ ${ }^{1}$ Student of MCA, College of Computer \& Information Science, Srinivas University, \\ Mangalore-575001, INDIA \\ ${ }^{2}$ College of Computer \& Information Science, Srinivas University, Mangalore-575001, India \\ E-mail: safiamh12@gmail.com
}

\begin{abstract}
The Smartphone manufacturer from China has a very novel business model wherein they manufacture cell phones in batches thereby keeping the inventory costs on a very low side. The company has really challenged the brick and mortar model and sell online, thereby cutting down the intermediaries and keeping the costs down for the company. The company sells smartphones almost on the cost price. The profit margin is very thin, and the company believes that they will make money by selling accessories and other complementary things. The problem which ascends now is that how Xiaomi would be able to adjust to the increased competition from other players like Huawei and ZUK from Lenovo who have imitated the same model. The second issue which has come to time light is that would this business model be sustainable over the long period. The third issue is how the company would react to the decline in the smartphone sales in China which has been one the main driving forces responsible for companies growth.
\end{abstract}

Keywords: Xiaomi, Company Analysis, Business Model, Smartphone.

\section{INTRODUCTION :}

Systematic collection of data and analysing them with a purpose and interpretation of the results to enhance the knowledge about or improving the understanding of anything can be regarded as research. Research can also consist of analysing any system in terms of its inputs, processes, and output with an intention to study the internal/external factors affecting the system performance [1]. Industry Analysis is a tool that facilitates a company's of its position relative to the companies that provides alike Services or Products. After identifying the problem, analyze and reduce the problem. If it's not possible at least try to reduce the effect of the problem. A good Paper includes all such elements. [1]. this paper discusses about the Xiaomi's Business Model with various studies and methodologies. Xiaomi has a vision of becoming a global company with a focus on creating user experiences from all aspects and has the mission of designing, developing, selling smart phones, cellular and electronic applications. Xiaomi's initial goal is to provide additional functionality that has not been offered on ordinary Android and provide an easy-to-use user interface. The goal developed according to the company's vision and mission so that in 2011, Xiaomi decided to enter the mobile market, not just limited to making software. The first product was named the Mi One, a high spec phone in its time but it was tilted. Xiaomi seems to have been consistent with the formula from the start[2]. The goal of Xiaomi is Xiaomi fans and users who want high-quality products with slanted prices so Xiaomi makes smartphones that are expected to keep up with technological developments for the next 18 months. In addition, Xiaomi also sells other smartphone accessories (power banks, earphones, etc.), household electronic equipment (TVs, refrigerators, etc.), additional application sales, online videos, and smartphone themes. For the long term, Xiaomi sees that hardware sales are only meaningful as an intermediary tool for users to be able to feel the software and services [3]. Like Xiaomi's own slogan, namely: "We are a company that is more focused on the internet and software than just a hardware sales company." 


\section{COMPANY PERFORMANCE :}

Xiaomi began entering the cellphone business sometime in 2011. Although the company's initial goal was to provide additional functionality not yet offered on ordinary Android and an easy-to-use user interface. MIUI, the ROM they created, were a huge success and were ported to various devices. Until 2014, MIUI could be downloaded and installed to more than 200 devices. In 2011, Xiaomi decided to enter the mobile market, not just limited to making software [5-7]. The first product was named the Mi One, a high spec phone in its time but it was tilted. Xiaomi seems to have been consistent with the formula from the start. Xiaomi is also fast growing in the mobile industry. In 2014, they had generated USD 5 billion in revenue, an impressive achievement for the newly established cellphone company. Mobile phone vendors from the Bamboo Curtain country then got the nickname 'Applenya' China.

The name was given because the new company that was built in 2010 has a very loyal user base, like the Apple fan boy. Including the style of the CEO Lei Jun who when making a presentation immediately reminded us of the legendary figure of Steve Jobs at Apple. Complete with black tops, jeans and sneakers. At present, Xiaomi cannot be called a mini company. According to Tech in Asia reports, Xiaomi has been worth USD 10 billion, equivalent to Rs 130 trillion (USD $1=$ Rs. 68). With a fanatical user base, Xiaomi's new cellphones, which are mostly sold online, are usually sold out quickly by fans. In fact, sometimes it makes a record of the short time until the cellphone is sold out. In 2012, Xiaomi recorded shipments of 7.2 million units of smartphone. Then in 2013, it increased rapidly to 18.7 million smartphone units. And in the first quarter of 2014, it sold 11 million units. Feeling quite successful in China, Xiaomi began targeting foreign markets [8-12]. Especially in the Southeast Asia region where the Indian market is included. As a result, it can be seen that Xiaomi easily won the hearts of smartphone enthusiasts in India.

\section{MAJOR COMPETITORS :}

Apple: Apple sells less than $20 \%$ of the smartphones but takes in 92 percent of the global smartphone profits (Exhibit 8).16 This thing reflects one only thing about the company and that is the ability with which Apple is able to continuously charge a premium price on its smartphones. As per the words of Denny Strigl, former Chief Operating Officer of Verizon communication Inc., This dominance of Apple is very hard to overcome. The company shipped a total of 47.5 million units with a decline of 22.3\% from Q1 of 2015.Overall iPhones saw a growth of 35\% year over year and a remarkable $51.4 \%$ in emerging markets.17 This data again shows how important developing markets are for companies like China, India, and Brazil.

Samsung Electronics: Even though Samsung couldn't keep up with the Apple's pace but Samsung sold 76million smartphones up from 72 during the same quarter of 2014. Samsung Electronics accounts for more than 70 percent of the group revenue. The company still has a huge dominance in the worldwide smartphone market and still has the highest shares of 21.9 percent.

Lenovo: Due to its strong dominance in Chinese markets, Lenovo has come from nowhere and established itself as the third biggest manufacturer of the smartphones throughout the world. Last year in February 2014, Lenovo claimed that its sales of smartphones in India have been increasing $100 \%$ per quarter while the market is only growing $15-20 \%$ over the same period. The company currently controls around 5 percent of the Global market share in smartphone industry. Further with the acquisition of Motorola an iconic brand at a valuation of around US $\$ 2.91$ billion Lenovo has made its presence felt not only in China but throughout the globe.

Others: LG is a South Korean multinational company headquartered in Soul and a member of LG group one of the biggest conglomerates in South Korea. The company currently controls around 4 percent of the global market share. Then there are companies like ZTE controlling around 3percent of the market share along with Coolpad controlling around the same market share by the ist quarter of 2015. This data is being witness to the fact that how Chinese companies have overtaken almost all the top eight spots in the global smartphone industry replacing the likes of Sony and Microsoft. 


\section{ENVIRONMENTAL ANALYSIS :}

At least, there are many factors that can be used as references by companies in order to carry out their business growth strategies, namely:

\section{(a) Social Factors}

Advanced technology is only owned by cellular companies that have a middle to upper market share while the average in the Asian region, especially in developing countries, there are people who have low income. From this there is a tremendous demand for technologically advanced smartphones but not yet at a fairly low price point that is affordable for working class people in developing countries. This is an amazing opportunity for Xiaomi [13-15].

\section{(b) Technology Factors}

Xiaomi has used the Android system to ensure that they meet the expected specifications of users and great performance. Xiomi has a slightly different and innovative technology from other smartphones that makes users feel more comfortable. So the technology factor they use is very supportive for Xiaomi's development from day to day.

\section{BUSINESS STRATEGY :}

(1) Autonomy in Processors Design: Till now Xiaomi use to rely on Qualcomm Snapdragons \& MediaTek chipsets, to provide the hardware support for the heavy UI they gave, but now they are moving towards autonomy by designing their Surge in-house processors to compete with Qualcomm Snapdragon 625 \&Mediatek P10 \& P20. This move can be seen as Xiaomi’s break in competing with the top leagues of Apple \& Samsung.

(2) Midrange Dominance : You get what you pay for, with a almost unity price to performance ratio, it becomes very difficult to beat Xiaomi in the market like India \& China where the majority population is middle class \& keep tight budget on smartphones. The affordable Redmi series is the everyone's apple of the eye.

(3) Quality Services : With 500 service centers across India, Xiaomi claims it has 'best in class' service delivery. Xiaomi also mentioned that it has three dedicated factories for repairs, two call centers with over 600 specialists, two large warehouses for spare parts, and a pick up and drop service that's available for more than 8000 pin codes across India.

(4) Innovation not only in Technology, but Business also :

1. Microsoft and Xiaomi to collaborate on AI, cloud computing and hardware - Techcruch

2. World's thinnest LED TV with AI content suggestions, MI LED Smart TV 4 under Rs 45000/-

3. Xiaomi launches Mi Music and Mi Video in India- BusinessLine

4. Xiaomi to bring 'crowdfunding' platform to India- Economic Times

(5) Customer Centricity : The reason which made Amazon a hulk in e-commerce is also the reason behind Xiaomi Success. Xiaomi has a very open environment $\&$ transparency in innovation. Lei Jun, the company's CEO, credits their customers for a third of the features added to their operating system and even for the exponential growth of the community of its users.

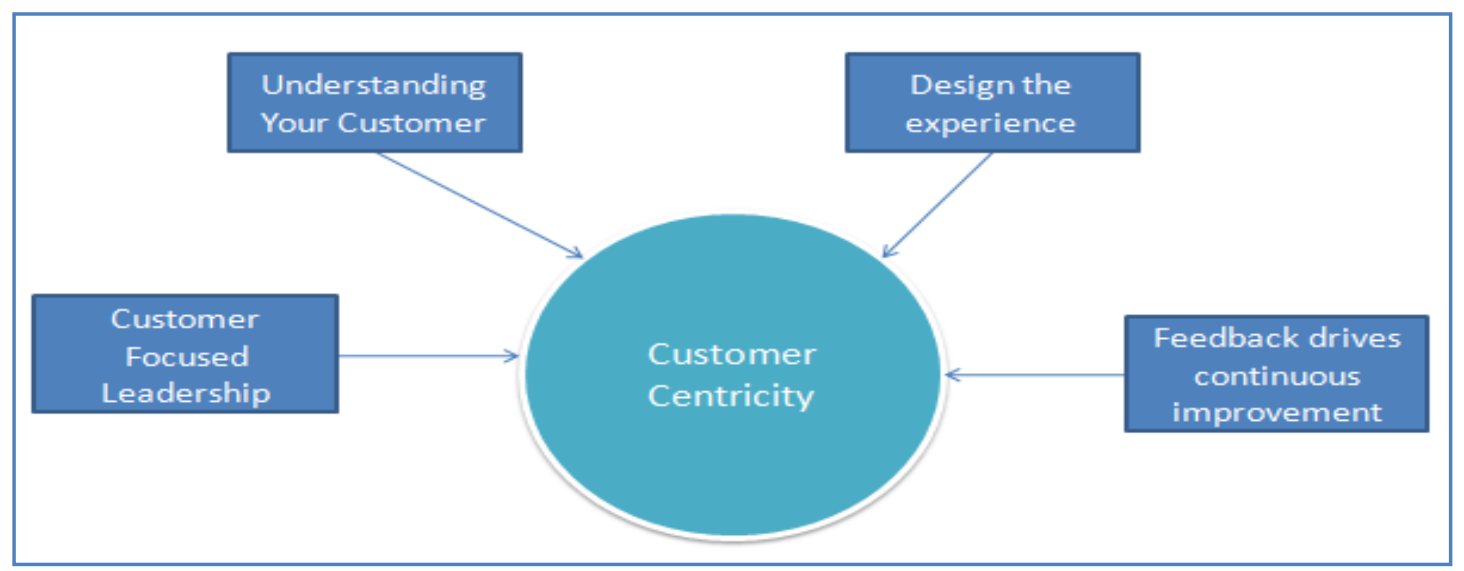

Fig.1: Customer Centricity 
An ecosystem that includes not just smartphones, but also branded fitness bands, power banks, air filters, smart home devices, and other technology products which shows the perfect blend of business, technology \& consumer satisfaction to make Xiaomi a global leader in technology \& been rightly tagged as "Apple of the East".

\section{ANALSIS OF INDIVIDUAL COMPETITORS :}

Xiaomi has already become the world's third largest smartphone manufacturer during a short span of time. A recent study claimed that Xiaomi accounted for six percent of all smartphones shipped worldwide, trailing solely Samsung (25 per cent) and Apple (12 per cent). Xiaomi hasn't even started selling those phones in the West yet. Its share will obviously grow. In China, Xiaomi is the No.1 maker with a 15 per cent share. Apple has scarcely started selling in China in earnest.

Due to Xiaomi's popularity, Samsung has lost the most market share within the last year in China, from 21 percent share to less than 14 percent. Having lost share and the leadership, Samsung will launch new devices in shortly designed specifically for China to reverse its fortunes. Lenovo and Huawei have done well to keep up their share, whereas the fortunes of the other Chinese vendors are mixed. Apple gets a boost when new iPhones are launched and has a loyal customer base.

Until now, Samsung and Apple are the two major companies dominating the smartphone market. Currently Xiaomi is set to be a serious player on a worldwide scale. Previously, it had been thought that only Apple and Samsung had the market leverage to urge customers to pay prices high enough to make profits in the phone business. There is growing evidence that Android's manufacturer is seeing itself squeezed in the markets. For this Xiaomi is solely responsible.

Samsung has already determined to bit by bit move aloof from expensive products completely, instead focusing in other markets. Apple is dominant in high-end, and Samsung is aware of it. The launch of the iPhone 6 has engulfed Samsung's market share, forcing it into make cheaper product.

So Apple must now plan for a world in which an Android manufacturer can sell high-end phones at a lower cost than Apple, it can make a profit. It has been assumed that Apple doesn't really compete against Android because Android makers compete against each other, and Apple catered the richest section of the market that wants to pay top-dollar for a good phone. But the numbers of Xiaomi implied the consumers in the future could be faced with a more complicated choice: An expensive iPhone or a less luxurious Xiaomi, both with similarly upscale designs or hardware.

While Apple is clearly not threatened by Xiaomi right now, the fact that Xiaomi has already upended one bedrock belief of smartphone economics suggests that you just should not assume it cannot undo others also as well.

\section{SWOT ANALYSIS :}

a) Strength

- Trusted brands in China.

- Prices are relatively cheaper.

- An innovative marketing approach.

- Effective online business model.

- Products that are flexible and have been adapted to the times.

b) Weakness

- Difficulty in getting loyal fanbases and supporting brands outside of China.

- Cheap distribution strategies may not be effective in other markets.

- Weak quality and after-sales service.

c) Opportunities

- Market demand will be high-tech phones at low prices.

- Expansion to retail channels.

- Creating a strong user experience and unique branding and ecosystem.

d) Threat

- War prices with other low cost competitors.

- Big competitors like Samsung are starting to enter the low cost market.

- Potential loss of control over the supply chain.

- Dependence on e-commerce as the main distribution channel. 
By knowing the SWOT that is owned, Xiaomi will be easier to implement what strategies should be applied to grow the company. Many ways to do growth strategies, for example by expanding the market, product development, integration of vertical, horizontal etc. To see how Xiaomi's own strategy can be seen next.

\section{TARGET PERFORMANCE :}

After having tasted rapid growth for several years, Xiaomi had to be a little disappointed because of the decline in their smartphone sales figures in 2015. The situation is complicated by the emergence of new competitors who follow in the footsteps of Xiaomi. So that Xiaomi inevitably has to make a change of strategy to be able to keep up with the intense competition in this field of technology [1921]. In accordance with the type of growth strategy, at least the targets that Xioami must achieve in the future are as follows:

\section{(a) More markets}

Market expansion basically tries to increase the marketing range of the types of goods that have now been produced. The company can expand its marketing area more globally to various countries in the international world. Companies must continue to be observant in seeing the market potential possessed by various countries in the international world. Moreover, seeing developing countries that are still very much in circulation, it needs special attention for companies in expanding their markets.

\section{(b) Flagship product}

With existing flagship products, it will support the market strength of the brands they have. This can be done, by making physical modifications to the display, or adding software performance. Obviously the most important thing is to make new and quality products, but also affordable.

\section{(c) Wider sales method}

Marketing is an important factor to support the success of a company. So, companies must continue to think about ways to make an effective marketing system. Because if they only make one system for marketing their products, of course they will lose competitiveness by other competitors. Even though it will be later, there will be more costs to do this. But eventually this will have a significant impact on the company's growth.

\section{(d) Products sell significantly}

The success of a company is certainly compared to the profit achieved. So from that Xiaomi also targets sales to increase significantly. Because seeing in 2015 the target was not in line with expectations. So, this needs to be a concern for the company[22].

The target desired by Xiaomi certainly must be realized with mature strategies. Although it should be remembered that in the global era like today where change is out of control, uncertainty is so high and competition is very tight. This is a challenge that must be faced by every company so that it can survive in global competition. The company must have various alternative solutions to solve the problems that arise which of course are in accordance with the current situation and conditions of the company and the decisions that will be taken will still be in accordance with the values of the company.

\section{CONCLUSION :}

Although Xiaomi has a very unique and novel business model and has done considerably well in such a short period of time but in spite of that the company is and will face some significant challenges which they need to overcome so that this burst prevails in long run. One of the biggest reasons for this huge success in such short run was the dominance of Xiaomi in Chinese market. The company had no close competitor in China which could beat them in price and quality but now due to the sudden rise of Huawei and Lenovo who has launched a separate subsidiary under the name of ZUK with a similar business model like Xiaomi, life is not going to be very easy for the company. Both the companies have started selling their devices online aimed at young price conscious users like Xiaomi. 


\section{REFERENCES:}

[1] Aithal, P. S., (2017). Industry Analysis - The First Step in Business Management Scholarly Research. International Journal of Case Studies in Business, IT and Education (IJCSBE), (ISSN: Applied), 1(1), 1-13. DOI: http://dx.doi.org/10.5281/zenodo.810347.

[2]Shih, C. C., Lin, T. M., \& Luarn, P. (2014). Fan-centric social media: The Xiaomi phenomenon in China. Business Horizons, 57(3), 349-358.

[3] Baxter, P., \& Jack, S. (2008). Qualitative case study methodology: Study design and implementation for novice researchers. The qualitative report, 13(4), 544-559.

[4] Gupta, S., \& Dhillon, I. (2014). Can Xiaomi shake the global smartphone industry with an innovative "services-based business model"?. AIMA Journal of Management \& Research, 8(3/4), 2177-2197.

[5] Dong, J., \& Zhang, Y. (2016). When customers become fans. MIT Sloan Management Review, 57(2), 95-96.

[6] Jia, J. (2015). A Theoretic Revelation of Strategic Positioning, Value Co-Creation and Innovation Performance. In International Symposium on Social Science (ISSS 2015).

[7] Heracleous, L. (2013). Quantum strategy at apple inc. Organizational Dynamics, 42(2), 92-99.

[8] Aithal, P. S. (2017). An Effective Method of Developing Business Case Studies based on Company Analysis.International Journal of Engineering Research and Modern Education (IJERME), 2(1), 16-27. DOI: http://dx.doi.org/10.5281/zenodo.400579.

[9] Reshma, Aithal P. S., Shailashree V T, Sridhar Acharya, P. (2015). An Empirical study on working from home - A popular E-business model.International Journal of Advance and Innovative Research, 2(2), 12-18. DOI :http://doi.org/10.5281/zenodo.164429.

[10] Aithal, P. S. \& Suresh Kumar, P. M. (2016). Theory A for Optimizing Human Productivity.IRA International Journal of Management \& Social Sciences, 4(3), 526-535. DOI: http://dx.doi.org/10.21013/jmss.v4.n3.p2.

[11] Reshma, Aithal, P. S.\& Sridhar Acharya, P. (2015). Relevance of On-line Office Administration through Working from Home in Future Education System. International Journal of Application or Innovation in Engineering \& Management, 4(4), $44-53$. DOI: http://doi.org/10.5281/zenodo.163882.

[12] Padmanabha Shenoy, and Aithal P. S., (2016). A Study on History of Paper and possible Paper Free World. International Journal of Management, IT and Engineering (IJMIE), 6(1), 337-355. DOI: http://doi.org./105281/zenodo.161141.

[13] Aithal, P.S., (2015). Comparative Study on MBA Programmes in Private \& Public Universities A case study of MBA programme plan of Srinivas University. International Journal of Management Sciences and Business Research (IJMSBR), 4(12), 106-122. DOI:http://doi.org/10.5281/zenodo.163884.

[14] Aithal P. S., and Suresh Kumar P. M., (2016). Analysis of Choice Based Credit System in Higher Education. International Journal of Engineering Research and Modern Education (IJERME), 1(1), 278-284. DOI: http://doi.org/10.5281/zenodo.161046.

[15] Varun Shenoy and Aithal, P. S. (2016).Changing Approaches in Campus Placements - A new futuristic Model. International Journal of Scientific Research and Modern Education (IJSRME), 1(1), 766 - 776. DOI: http://doi.org/10.5281/zenodo.160966.

[16] Aithal, P. S. (2017). Industry Analysis - The First Step in Business Management Scholarly Research. International Journal of Case Studies in Business, IT and Education (IJCSBE), 2(1), 113. DOI: http://dx.doi.org/10.5281/zenodo.810347. 
[17] Aithal, P. S. (2017). An Effective Method of Developing Business Case Studies Based on Company Analysis. International Journal of Engineering Research and Modern Education (IJERME), 2(1), 16-27. DOI: http://dx.doi.org/10.5281/zenedo.400579.

[18] Aithal, P. S. (2017). Company Analysis - The Beginning Step for Scholarly Research. International Journal of Case Studies in Business, IT and Education (IJCSBE), 1(1), 1-18. DOI: http://dx.doi.org/10.5281/zenodo.573769.

[19] Aithal, P. S., (2017). ABCD Analysis as Research Methodology in Company Case Studies. International Journal of Management, Technology, and Social Sciences (IJMTS), 2(2), 40-54. DOI: http://dx.doi.org/10.5281/zenodo.891621.

[20] Jithin Raj, K. \& Krishna Prasad, K. (2018). A Critical Study on Business Strategies of 3i Infotech Ltd. International Journal of Case Studies in Business, IT and Education (IJCSBE), 2(1), 13-21. DOI: http://dx.doi.org/10.5281/zenodo. 1247319.

[21] McCarthy, N. (2018) Which Smartphones Emit the Most Radiation? Forbes, Retrieved from https://www.forbes.com/sites/niallmccarthy/2018/03/01/which-smartphones-emit-the-mostradiation-infographic/\#10eede501b04.

[22] Einhorn, B. \& Chen, L.Y. (2018) Sexist Job Ads Show Discrimination Rife at China Tech Giants. Bloomberg, Retrieved from https://www.bloomberg.com/news/articles/2018-0423/sexist-job-ads-show-discrimination-rife-at-china-s-tech-giants. 